\title{
Designs on the Future: Aboriginal Painted Shields and Baskets Of Tropical North Queensland, Australia
}

\author{
Bård Aaberge
}

Trish Barnard

Shelley Greer

Rosita Henry

James Cook University

\begin{abstract}
Iconic painted shields and baskets made by Aboriginal people of the North Queensland rainforest region have been collected and placed in museums all over the world. We describe the historical ethnographic context of the production and use of these things and explore transformations in their value through time. These things are of value to museums and were of value to the collectors who originally procured them. They were also of value to the Aboriginal producers and are of value today to their descendants. We reflect upon the concept of value by considering the different values that inform how the shields and baskets were valued in the past, and how their worth continues to be evaluated today.
\end{abstract}

$\mathrm{O}^{\mathrm{b}}$ bjects made by Aboriginal people of the North Queensland rainforest region have historically been collected as artefacts and placed in museums all over the world. Today, there are numerous Aboriginal artists who refer to, or draw upon, these museum objects in the creation of contemporary art works.

In this paper we focus on rainforest Aboriginal artefacts in relation to the concept of value. These objects were of value to museums and to the collectors who originally procured them. They also were of value to the Aboriginal producers and continue to be of value today to their descendants. There are many different values that inform how the worth of these objects was, and continues to be, evaluated.

We argue that to value something involves an active process of evaluation which, whether one is aware of it or not, requires one to draw upon certain values. In any such process, particular values may be dominant and others muted. As Gregory notes, people create and constantly switch between multiple value systems according to political context (8). Thus, value relations are by definition political relations and entail contestations of power (see Gregory 33; Strathern 218-19). 
In pondering the problem of how to determine the values, and the nature of the value relations, that inform how particular material things are valued, we have chosen to focus on two types of artefact that are iconic to the rainforest region of North Queensland. These are the large painted shields and the distinctive bicornual baskets that are woven from lawyer cane (Calamus moti), a type of rattan. We have chosen these things for a number of reasons, but mainly because of their particular interest to early artefact collectors, possibly because of the striking designs painted on the shields, and the unique engineered shape of the baskets.

\section{Rainforest Shields}

The rainforest shields were highly prized among collectors because of their distinctive, painted designs.

Most colourful of all types of Australian aboriginal shields ... were the painted shields of North-eastern Queensland, without doubt among the most beautiful of all aboriginal works of art, richly painted with broad bands of white, yellow, red, redbrown and black, with totemic designs representing certain trees, fish, insects, leaves, fruit, initiation marks, and natural phenomena. (Mountford 1)

The shields were made from the buttress roots of rainforest fig trees (Ficus sp.). They protected their owners in battle and featured a 'boss' that may have provided additional protection for the hand (Figure 1).

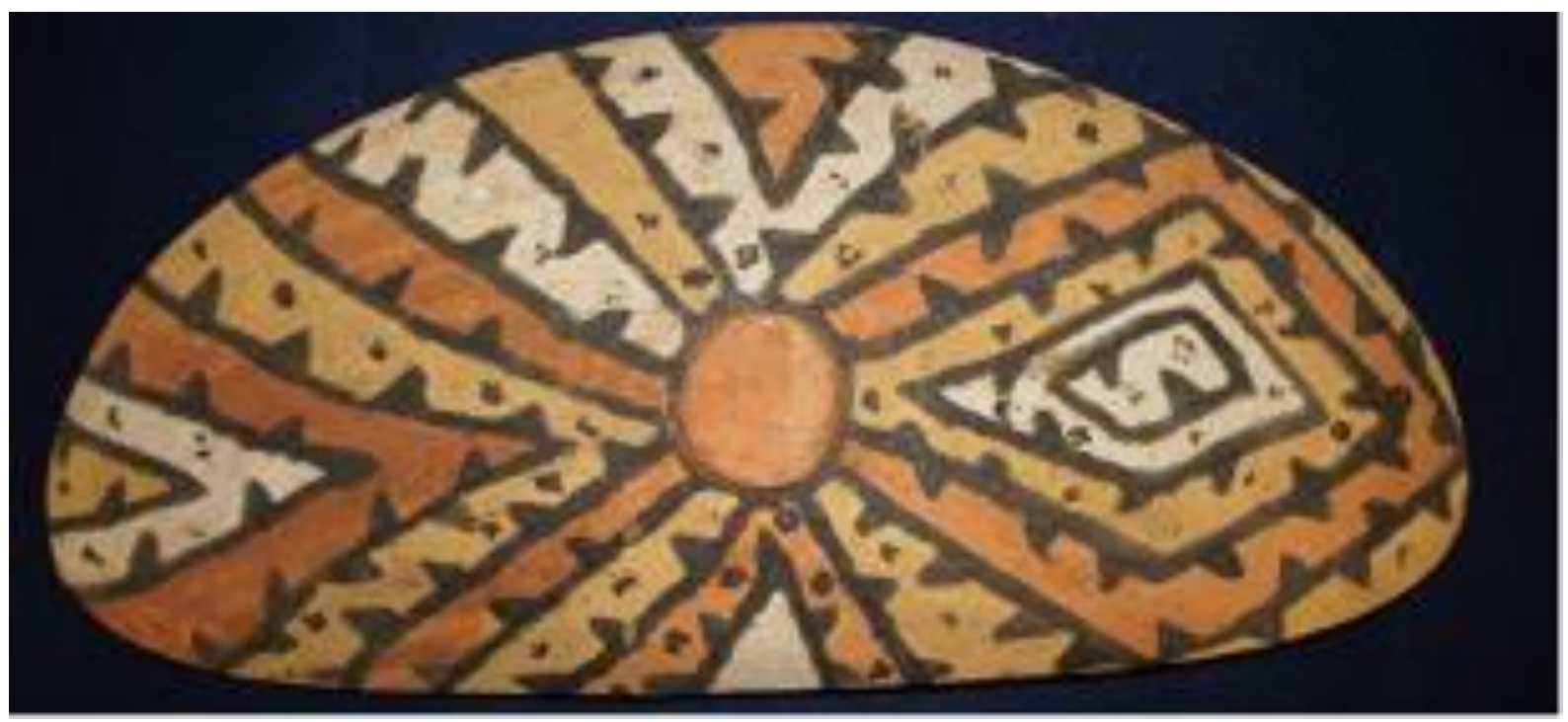

Figure 1: Rainforest shield, James Cook University Material Culture Collection. Photograph by Rosita Henry

According to Abernethy there are regional differences in the way that the shields were made, including the shape of the shields and the form of the handles. Different processes were also undertaken in their production. In all instances, however, one side was smoothed in preparation for painting (Johnson $\left.{ }^{1} 153\right)$.

The designs were painted in natural pigments of red and yellow ochre, white pipe clay and charcoal. Some shields feature only two colours while others have three or all four colours.

\footnotetext{
${ }^{1}$ Since 2003, Trish Johnson has reverted back to her maiden name of Barnard.
} 
There are also shields held in museums that include areas painted with Ricketts blue, which became available to Aboriginal people in the post-contact period (Figure 2).

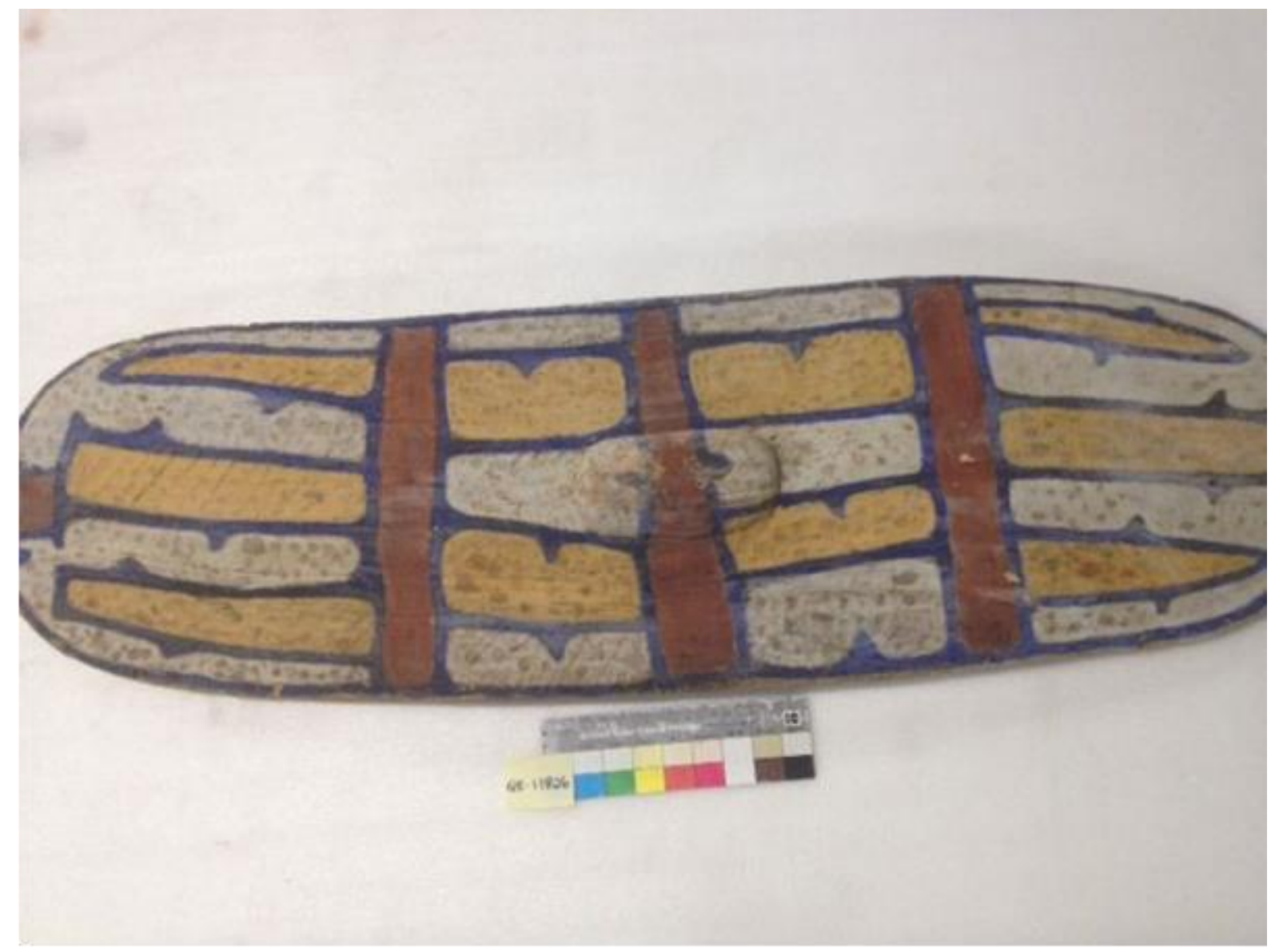

\section{Figure 2: Shield, c.1900, Queensland Museum QE11826, collected at Stone River Station, west of Ingham.}

In most cases, motifs are outlined in black. Black is also used over other colours to create dots or cross-hatchings (Abernethy 73-74). Johnson notes that the black pigment was produced by mixing charcoal with human blood (156). According to Michael Boiyool Anning (qtd. in Johnson 156), his grandmother told him that men would make their noses bleed by pushing a piece of lawyer cane up their noses and 'spot their shield with it all - and in a way [it] puts their life into the shield by putting blood into it'. As Johnson reports, the shields were a '...significant component of a male's possessions - the designs identifying them and their country to other groups' (153).

\section{Shield Designs}

There are several different approaches that might be taken in interpreting the designs on the shields. One approach among anthropologists of art and material culture is an iconographic analysis which looks at general principles of design (motifs, composition, colour and other design elements), and attempts to relate them to the geographical and/or social context in which the designs are painted and displayed (Hale; Best; see also Lowman, and Alland for typical examples of this style of analysis in relation to shields of the Maring people of PNG). Another approach is a semiotic one, focusing on the complex layers of meaning or symbolic value of the designs as a whole, as opposed to merely eliciting and documenting iconic referents - objects, flora, fauna, and so on, that the motifs are said to represent. 
Yet, the anthropological study of art is not confined to the study of its symbolism and meaning. According to Alfred Gell, an anthropological theory of art should go beyond the study of art as simply a communicative system. It should be the study of social relationships in a particular domain, 'a domain in which "objects" merge with "people" by virtue of the existence of social relations between persons and things, and persons and persons via things' (12). For Gell, '[a]rt is a means of changing the world (rather than merely encoding symbolic propositions about it)' (6). Similarly, Evans-Pritchard described Nuer spears as 'chains along which social relationships run' and argued that the material culture of a people can be understood in terms of 'the relationships expressed through it' (89).

The shields we have examined that are held in museum collections, are each unique in the sense that no two designs appear to be identical. However, there is little documentary evidence as to the context of their production and meaning - either the European collectors did not elicit information on what the designs might signify from the Aboriginal producers or such documentation was not provided to the museums. The late $19^{\text {th }}$ Century naturalist and collector, Carl Lumholtz observed shields in use during a ceremonial dispute resolution gathering near Herbert Vale in the late $19^{\text {th }}$ Century (Figure 3). He noted that 'the front is painted in a grotesque and effective manner with red, white and yellow earth colours, and is divided into fields which, wonderfully enough, differ in each man's shield, and thus constitute his coat of arms' (121).

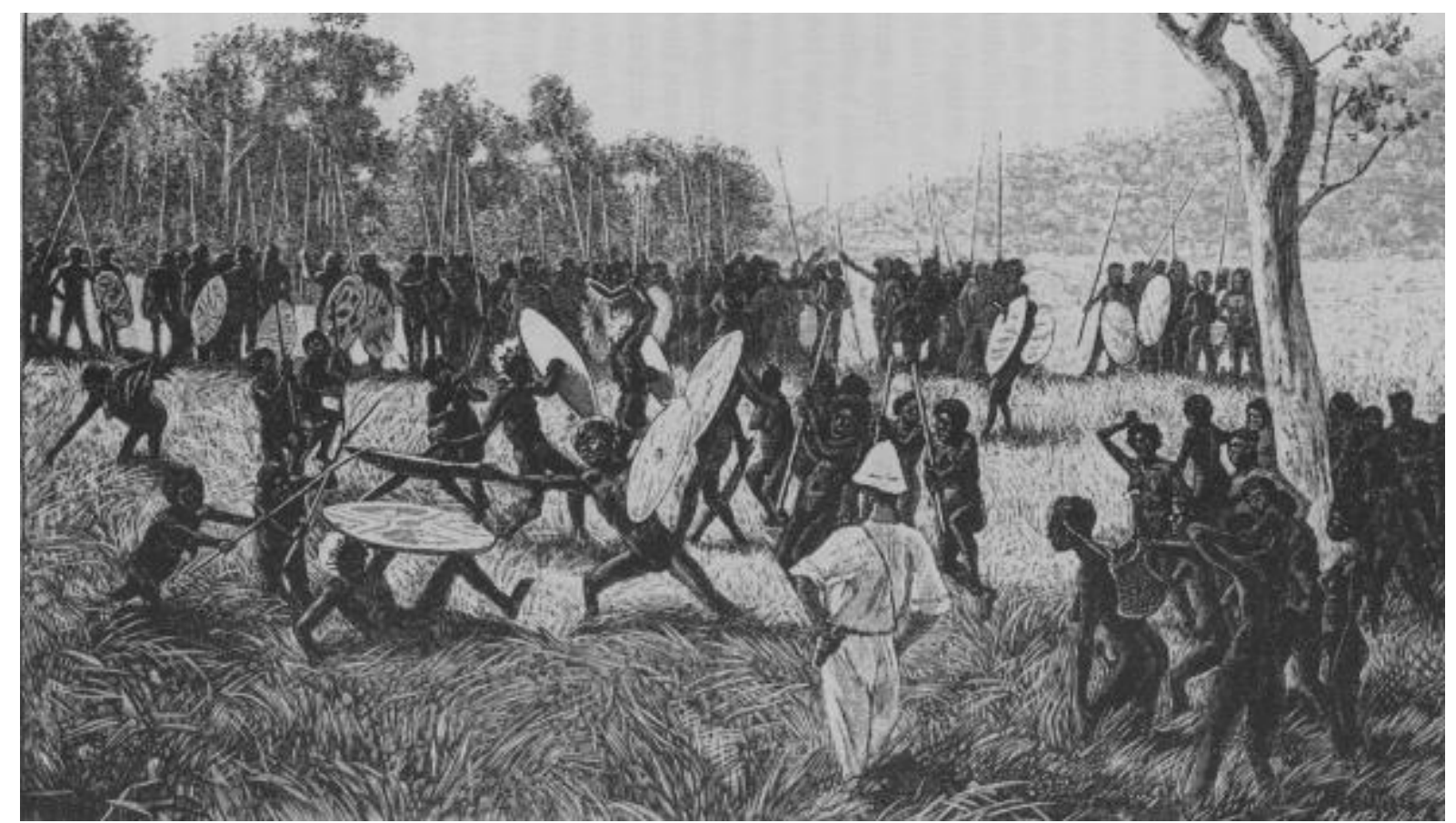

Figure 3: Sketch of a ceremonial dispute resolution duel that Lumholtz witnessed in 1882 near Herbert Vale (Lumholtz, to face page 124)

Anthropologist Ursula McConnel provides the earliest (and perhaps only) published ethnographic interpretation of the significance of shield design. She collected several shields that were especially made for her. According to McConnel a young man would be given an unpainted shield of his own during the final day of day of his initiation after which he 'thinks what he is going to put on his shield' in terms of the design (56). McConnel suggests that this design (or what the young man 'thinks' to put on his shield) is a representation of the 
dreaming ancestor associated with the new totemic name that the young man is given after initiation 'on whose protection he would certainly have counted in a fight' (56).

McConnel records that the motifs or designs painted on the shields include the tomahawk, the boomerang, the bark waterbag, the leaves of the tree from which boomerangs are made, the leaves of the tree from which a cure for stinging nettle is obtained, the leaves of edible fruit trees, the pods and seeds of a bean from which flour is ground, the tree grub, fish of various kinds, the backbone of the salmon fish, stars, comets, and the rainbow (50). On two Yidinji shields she recorded what she was told was a white scorpion design and a design that was said to represent drops of blood that were drawn from the nose during rituals. On a Gunggandji shield she recorded a design representing two parent turtles with numerous offspring, on another the inkfish, and yet another, the starfish.

Given the ritual context in which shields were conferred on individuals, and the fact that their designs were inspired by totemic affiliations, the painted shield physically and visibly situated the individual within a web of cosmological relations. Yet, European observations of shields were primarily focused on their role in 'battles' and their physical properties in protecting the combatants (eg. Lumholtz 119-127). From an Indigenous perspective it is likely that the shields had more than merely utilitarian value in terms of physical protection; they were a visible sign or emanation of the concealed body and perhaps also the concealed ancestral spirit who may have offered protection. The shield is a form of embodied knowledge that acts as substitute for the human body - a symbol not only of the person in his entirety but also a symbol of his expanded self, that is, his relationships with others. The shield covers the entire body, protects the body, is painted by and with the body (blood) and links the body (through totemic design) to clan.

\section{Rainforest Baskets}

Bicornual baskets from the north Queensland rainforest region are unique within the many types of woven baskets made by Aboriginal people in Australia, particularly because of their 'engineered' shape which features a rigid basket with two 'horns' on the bottom (Figure 4). The shape is partly facilitated by the lawyer cane from which it is made, which is highly flexible yet durable, especially in damp conditions. 


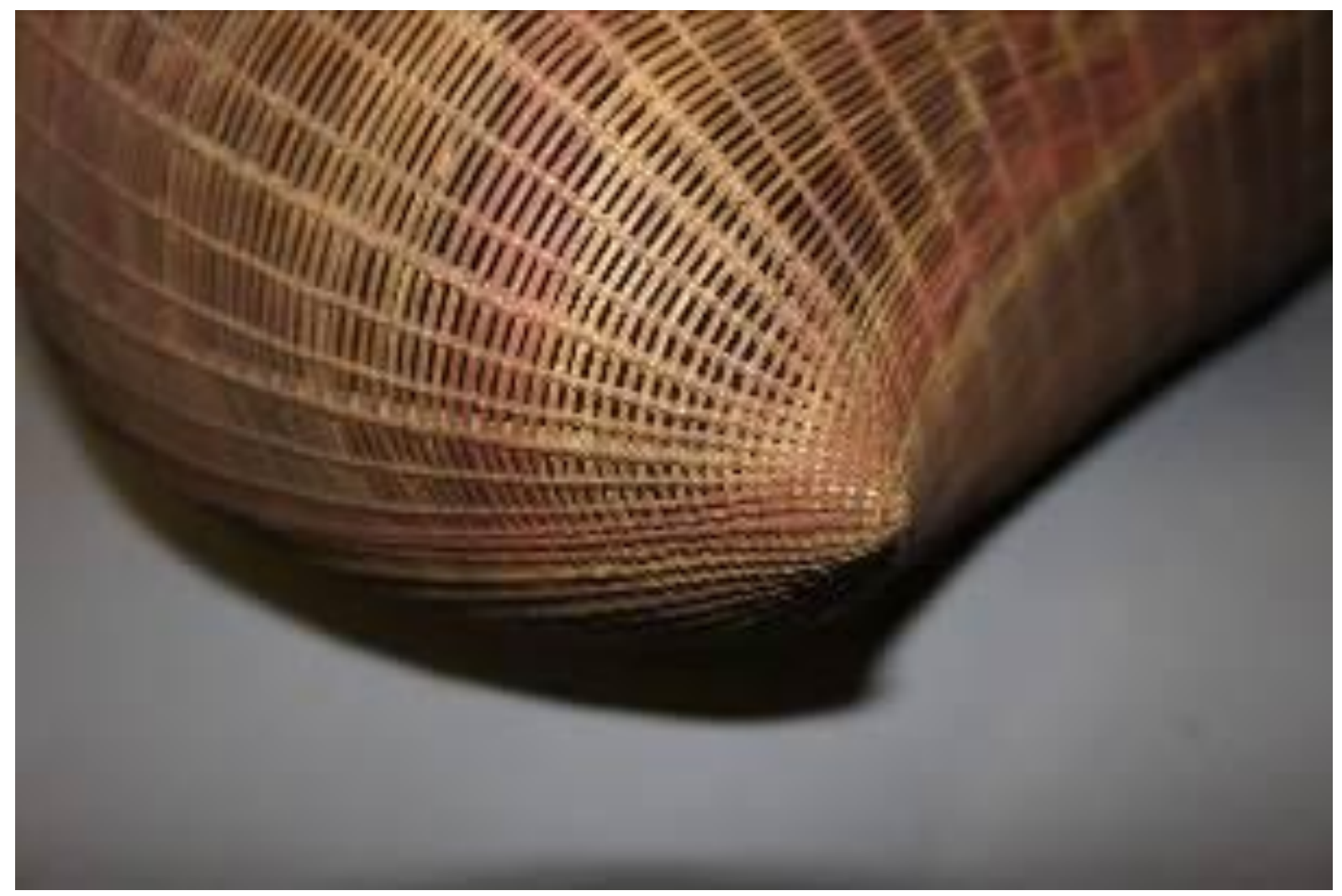

\section{Figure 4: Detail of bicornual basket collected by Klaatsch, Rautenstrauch-Joest Museum, Cologne. Photograph by Rosita Henry}

In a livelihood sense, the baskets had many uses including leaching of toxins from seeds and nuts. These were placed in the baskets and the 'horns' were wedged between sticks or boulders which kept the basket in place while allowing the running water to leach the toxins. This efficient process also acted as a small, movable fish trap as fish were also caught in the basket (Ewington 161).

Bicornual baskets were also used for carrying babies and as a receptacle for collecting and storing food. When used for these purposes, the baskets had two handles: a longer twine handle which was looped over the forehead for carrying and a shorter handle which was used to hang the basket on a tree branch or in shelters.

Decorated baskets, those with designs painted on the front of the basket, had special functions. According to Ewington they could have been 'gifts to family members or to other groups to mark auspicious occasions' (161). That baskets were made for the purpose of gifts in ceremonial exchanges is evidenced by Lumholtz although the baskets he received - for which he provides a sketch - do not appear to have had any designs painted on them (Figure 5). 


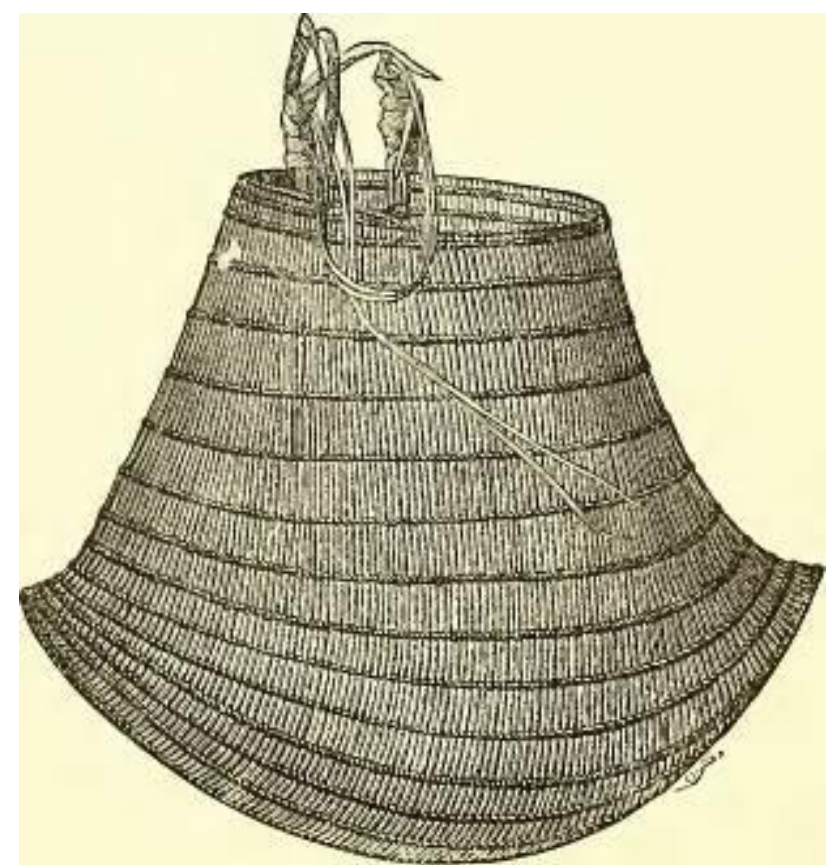

Figure 5: Sketch by Lumholtz of a bicornual basket given to him in 1882 (Lumholtz 190)

To show us that we were welcome, they sent us a present, consisting of two large baskets, to our camp, which we made close by. It was an act of politeness which my blacks expected, and had mentioned to me in advance. The baskets were very nice, in fact admirable specimens of native handiwork. (Lumholtz 192)

Baskets that were painted may have been associated with mortuary rites (Ewington 161). According to Erckenbrecht, one of the bicornual baskets collected by Hermann Klaatsch, which is now in the Rautenstrauch-Joest Museum in Cologne, actually contained mortuary remains. It is possible that the particular design painted on the basket marked the identity of the person whose mortuary remains were contained within. On the other hand, like the shields, men may have decorated particular baskets with totemic designs as part of initiation or other ritual practices. Lumholtz notes that the baskets 'are often painted with red, yellow, or white ochre, and sometimes with stripes or dots of human blood, which the maker takes from his own arm' (194) (Figure 6). 


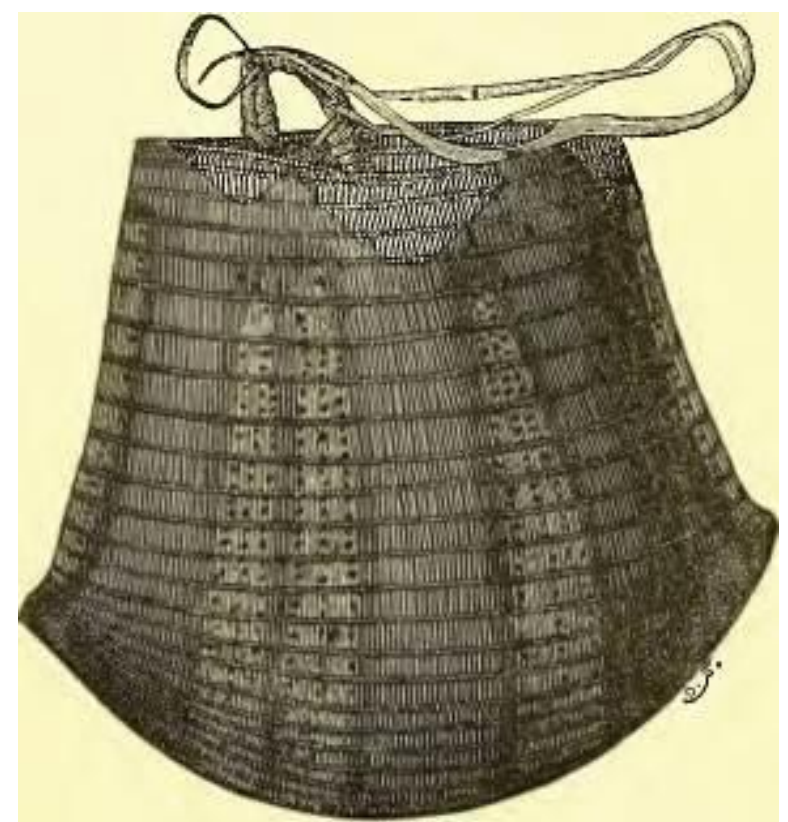

\section{Figure 6: Basket from Herbert River, painted with stripes and dots of human blood (Lumholtz 1889: 195)}

It is possible that the designs painted onto the baskets were related to the designs on rainforest shields but the relationship between the two remains unclear (Ewington 161).

According to Lumholtz '[o]nly the men plait baskets - the women never' (193). In 1913, Mjöberg also documented that the lawyer cane baskets were made 'exclusively by older men' (qtd. in Ferrier 18). Nevertheless, it is clear that women used these baskets. As evidenced in old photographs, bicornual baskets were used by women for processing food and for carrying babies. However, it is unlikely that the baskets used for such purposes were painted.

\section{Values of Difference and Dominance}

According to Graeber value can be defined 'as a way people's own actions become meaningful to them, how they take on importance by becoming incorporated into some larger system of meaning' (451-2). Graeber suggests that one way anthropologists might practically ascertain what people value is by paying attention to what they put their creative energies into.

Certainly, the Aboriginal producers who made and painted the shields and bicornual baskets, now held in museums, put creative energy into their production. The act of painting designs on these objects is a process by which certain values are made apparent. Both the baskets and the shields are tangible evidence of valued social relationships. They carry totemic designs that link their makers into the broader cosmological network of ancestral connections and they were associated with important life-cycle events and rituals that played a significant role in the constitution of personhood, as well as playing a role in everyday subsistence. Mjöberg provides evidence that the painted baskets had such value to the Aboriginal people at Cedar Creek, near Ravenshoe, that they chose to hide them from him:

At Cedar Creek some baskets had red figures and other patterns painted with human blood but the natives hid them in the rainforest when I came to collect them. (qtd. in Ferrier 18) 
However, it is not just in making things and in painting designs that people invest creative energy; they also invest creative energy in the transactions and relationships involved in the process of the creation and subsequent use of these objects, including their trade and exchange. Such material transactions inevitably involve power relations between the transacting parties. As Carrier notes, '...the link between a person and an object can be denied, and those who are persistent and powerful are likely to be able to make such a denial stick. Those who wish to maintain their links with an object need to have the power to do so' (89). Carrier distinguishes three types of power relevant to claims that people make concerning objects in Melanesia. These types of power also apply among rainforest peoples in Australia: 'knowledge of clan history/genealogy with good speakers able to convincingly express this knowledge, strength of numbers and the persistence to maintain a steady stream of disputes that will wear down the weaker opposition; intimidation' (97).

After the European collectors came on the scene, agency and creative energy was then also invested by Aboriginal people in developing relationships with these newcomers. The collection of ethnographic artefacts provided entrepreneurial opportunities not only for collectors but also enterprising Aboriginal individuals who 'realised that artefacts were a commodity for exchange with outsiders' (Allen 30). Questions may have arisen regarding who had the right in any particular local group to actually engage in the artefact trade, and to 'sell' objects to collectors.

The collectors quickly realised that the product that Aboriginal people desired or valued most highly, and for which they were more likely to give up valued objects, perhaps even against their better judgement, was tobacco. Lumholtz notes that: 'As money I used tobacco... When I ran short of tobacco I was always obliged to go back to the station' (106). Lumholtz reflects on the value of tobacco to Aboriginal people of the Herbert River and notes that it is something 'which they value so highly that they sometimes wrap a small piece of about four inches long in grass, in order to enjoy it later or they may send it in exchange for other advantages to another tribe' (106). In other words, tobacco was highly valued because it enabled the Aboriginal artefact sellers to develop relationships and pursue political advantage within their own social spheres.

The collectors, in turn, invested a great deal of creative energy in transacting with the Aboriginal people from whom they hoped to obtain artefacts and also in multiple social relations with other brokers along the value chain. Similarly, the museums they supplied invested energy in arranging and displaying these objects according to particular values (Foster; Henry, Otto and Wood; Kirshenblatt-Gimblett; Penny; Peterson, Allen and Hamby).

Aboriginal cultural material was collected not only by professional scientific collectors but also by local settlers, public servants, explorers, graziers, traders and photographers from the time of first exploration of Queensland in the $19^{\text {th }}$ Century. The collectors could make good profit from selling Aboriginal things either directly to museums or to business houses that specialized in the sale of artefacts. The trade in artefacts intensified as the desire for Australian things by European museums increased in the second half of the $19^{\text {th }}$ Century following the international exhibitions, beginning with the Great Exhibition of 1851 in London (see Penny on the values driving the competition between German museums for the best collections of artefacts from the colonies). 
There was clearly some prestige attached to these activities. Academic collectors, such as Professor Hermann Klaatsch, delivered public lectures during their travels through north Queensland. Perhaps this inspired some of the local settlers to follow suit. Collecting was perceived as a 'gentlemanly' activity that could be undertaken in the colonies (see Henare for comparative artefact collecting and exchange practices in relation to New Zealand and contributions to O'Hanlon and Welsch in relation to collecting activity in Melanesia).

One such collector was Joseph Campbell (1856-1933), who was archdeacon and rector at Cairns from 1904 until 1909. He also gave courses in mineralogy and mineral exploration and conducted research on tropical agriculture. In 1910, he developed Gossypium Park cotton plantation, south of Cairns, which employed local Aboriginal labour. In 1916, Campbell sold a collection of artefacts, including shields and baskets, to the Queensland Museum for 30 pounds. Some of these were probably made specifically for sale by Yidinji men working on the plantation. One of the bicornual baskets contains remnants of cotton, evidencing that it was used by the cotton pickers.

Another collector was Derwent Vallance (1875-1960), who settled in Cairns in 1898 (Pearson). In early 1900, he sent 99 artefacts that he had collected in the Cairns region to his sister Florence Walker, in England. In a telegram, he requested of her:

Take care of this and put it away carefully. It is a catalogue and inventory of what I sent you and will assist you in arranging them perhaps. Do display them well as they are really a very fine collection (his emphasis). (British Museum files)

He placed a monetary value on his collection, but the collection clearly had significance for him that went beyond its commercial worth. Thirty years later, Florence Walker gifted the artefacts to the British Museum, where we were able to examine them in 2012. Among the things he collected were at least nine painted shields. It seems that Vallance was as much interested in the different designs on the shields as he was in the shields themselves as an artefact 'type'. While the designs appear to have had aesthetic value for him, unfortunately, as was the case with most other collectors, he did not document the significance that the shield designs may have had to the Aboriginal people who painted them.

\section{Values Informing Contemporary Aboriginal Creative Works}

The past few decades have seen a resurgence of interest among Aboriginal people in the objects that their ancestors made. During the 1980s Aboriginal peoples of the rainforest region became increasingly interested in pursuing what they referred to at that time as 'cultural revival'. This cultural revitalization, or renaissance, movement included active efforts to access artefacts and old photographs of their ancestors that were held 'in captivity' in museums all over the world. For example, in 1982 two members of the Kuranda Aboriginal community took a course in museum studies and then worked to create a small local museum, which they named Jilli Binna ('eyes' and 'ears'). Access to museum collections fostered the ability of a new generation of rainforest Aboriginal artists to turn to ancestral works for creative inspiration (Erckenbrecht 360).

In particular, there has been an efflorescence of artistic works that reference the rainforest shield, a unique combination of both sculpture and painting. Perhaps artists can relate to the shield easily as 'among all the implements humankind might have carried with it in the past, it is the shield that lies closest to the concept of "picture" (Boyer 11); the frontal facing plane 
of representation makes it easily adaptable to art gallery walls. It may be that artists particularly turned to the shields their ancestors made because the shield, of all cultural materializations, was traditionally an object that was intended to be seen or displayed. The shield is an object to be shown and exhibited. It embodies the warrior more completely than the spear since, at a glance, it seems to provide the distillation of an entire culture.

(Boyer 15-16)

Aboriginal Artists who have reproduced shields as fine art include Danie Mellor, Vernon Ah Kee, Paul Bong, Michael Boiyool Anning, and Roy Gibson. Anning has been making and painting shields for many years. His works reference designs on Yidinji shields that are held in museum collections (Figures 7, 8 and 9).

\section{QE1142}

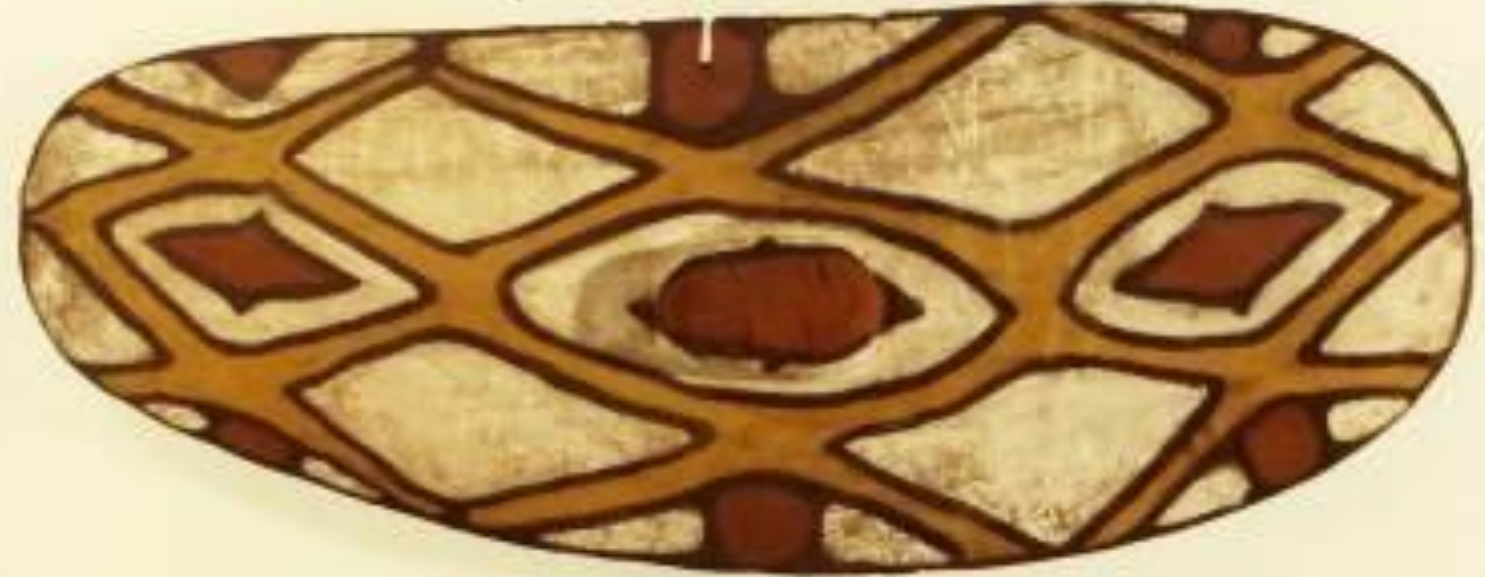

Figure 7: Shield by a Yidinji man at Wrights Creek, 1914. Queensland Museum, QE1142

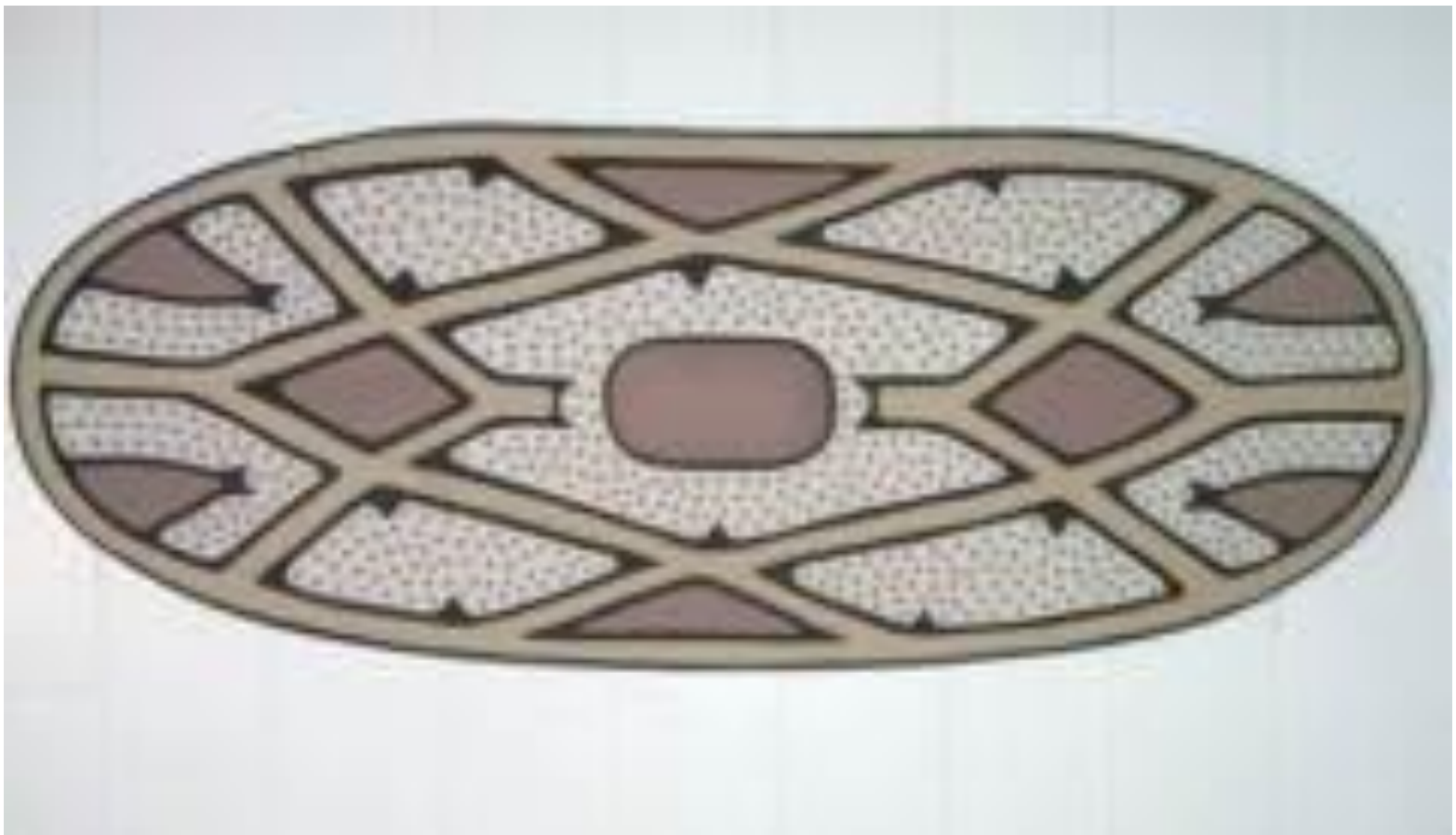

Figure 8: Shield by Michael Boiyool Anning, (c) 2011. Queensland Museum, QE-40655 


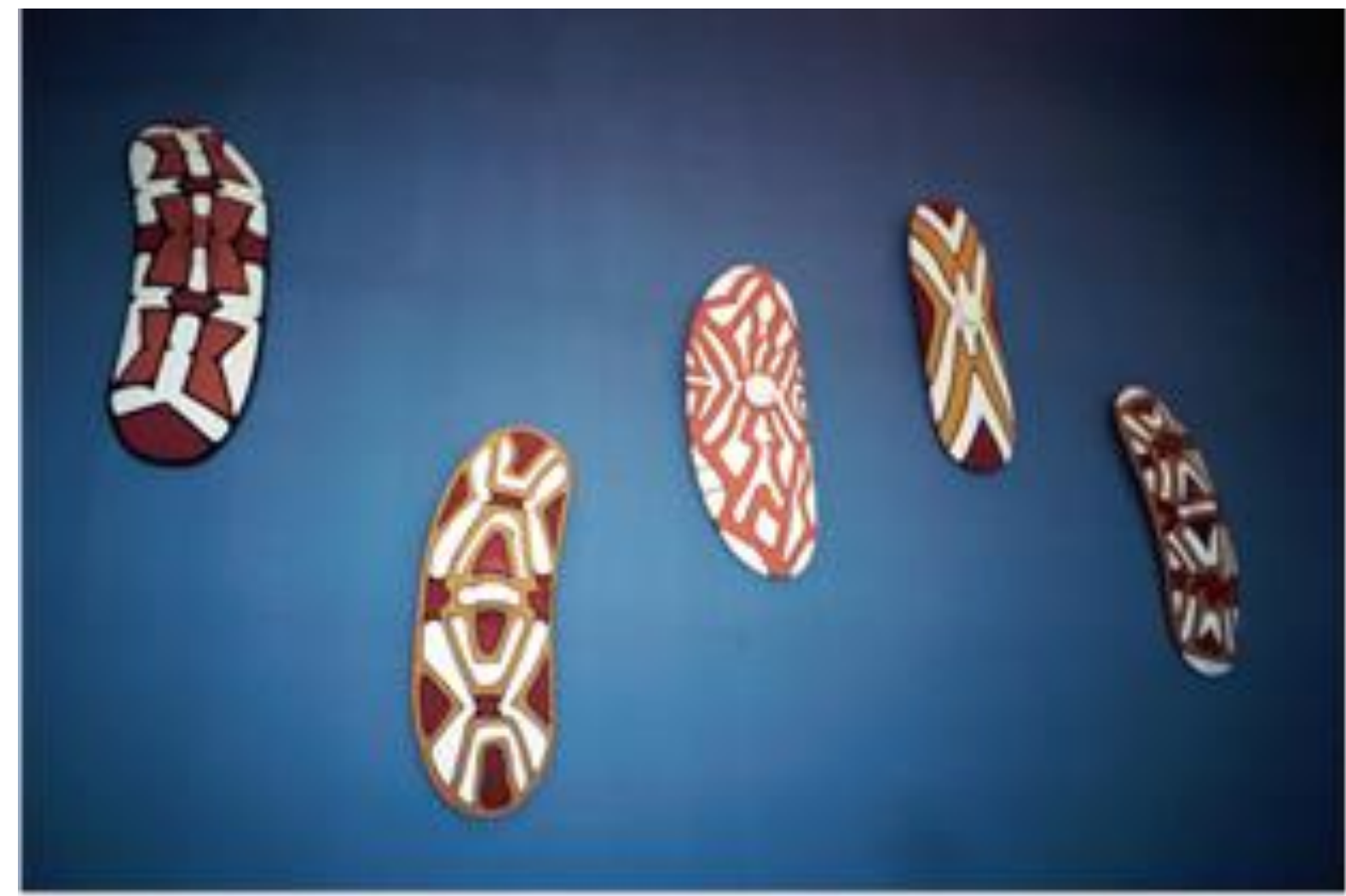

Figure 9: Michael Boiyool Anning's (C) shields on display in the Cairns Convention Centre. Photograph by Trish Barnard.

Similarly, Paul Bong began to paint shields, which his uncle had carved for him, over twenty years ago. These are hanging as an installation in the Brisbane airport. More recently, artists have begun to create fiberglass, bronze and ceramic shields and to transpose shield designs onto other media. For example, Vernon Ah Kee has put shield designs onto surfboards and Djabugay artist Napoleon Oui features rainforest shield designs, including the central boss, in his paintings and prints (see also painting by Paul Bong in Figure 10). 


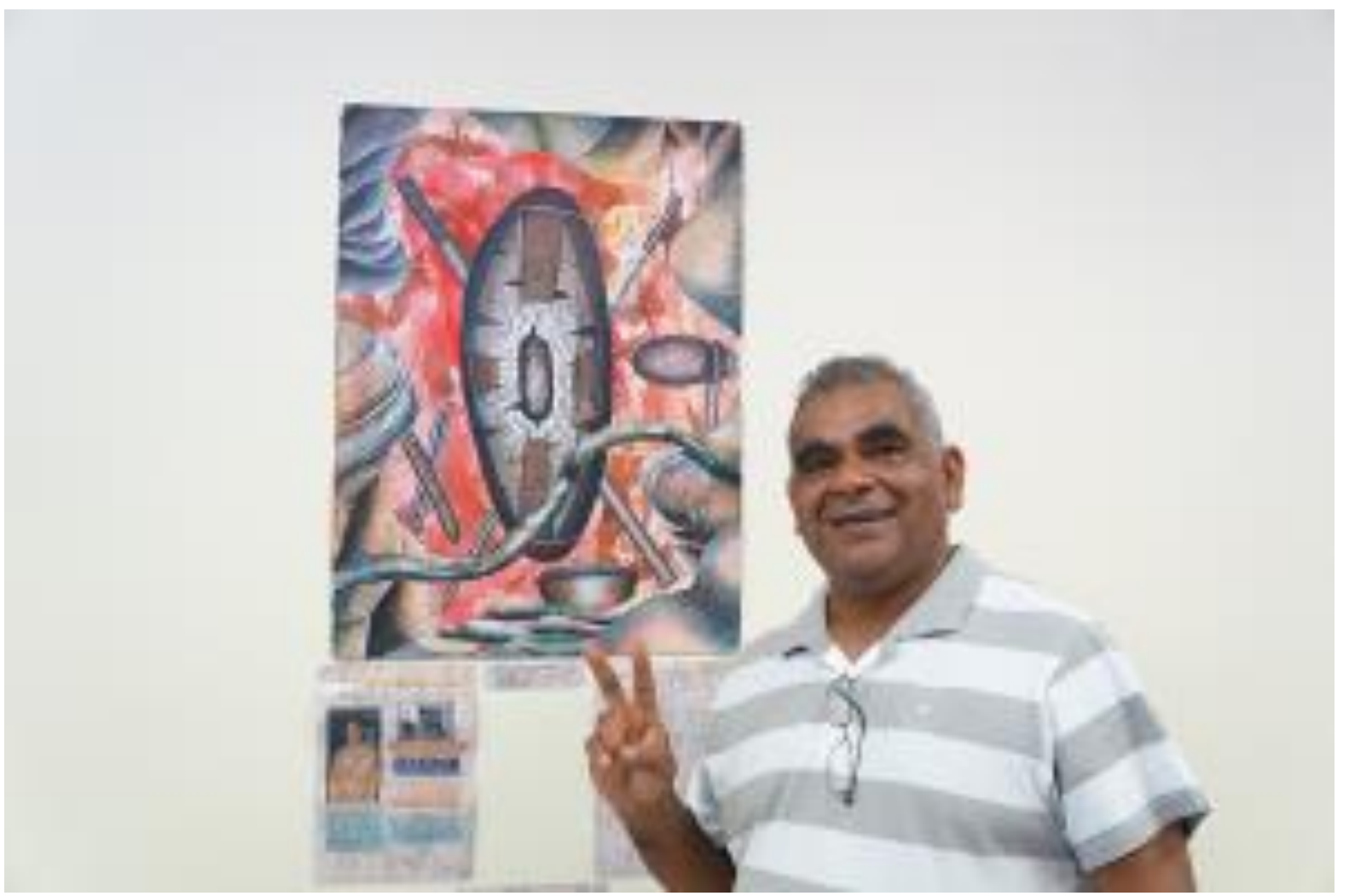

Figure 10: Paul Bong with one of his paintings, (C) 2012. Photograph by Rosita Henry

Our ethnographic research reveals that the rainforest shields, baskets and other objects once avidly collected for the museum trade continue to have cosmological significance for rainforest Aboriginal people today. These things are embroiled in 'new and different kinds of relationships' in a number of different arenas in addition to the art industry and the world of fine art. They are involved in complex relations of power and inequality and they are embedded in contemporary social and political relations among rainforest Aboriginal peoples themselves, pursuing their own cultural goals 'within a matrix of local inequalities and power differentials' (Ortner 144). One such arena is native title where contestations of traditional ownership of land and artefacts take place both within and outside the courtroom, between the state and Indigenous people, as well as between different Indigenous groups or families. In this sense, the contemporary shields, woven baskets and other such things, continue to be 'agentic objects', embedded in webs of relations. They are mediatory things, enabling a 'capacity to act', and empowering rainforest Aboriginal people to respond to forces of domination and subordination.

The way rainforest people today are engaging with museum artefacts and transposing the designs is exemplified by the case of Kuku Yalanji artist, Roy Gibson's approach to contemporary shield art. In March 2009, Bård Aaberge, was contacted by a community arts coordinator in the region (Mossman Gorge) to help track down photographic and archival documentation of traditional designs collected from localities in Kuku Yalanji country (tribal territory). Aaberge emailed the arts coordinator a copy of a photo of a shield that was collected in Kuku Yalanji country, now in the Roth Collection in the Australian Museum, along with his research report regarding North Queensland rainforest shields that he was preparing for the Cairns Historical Museum. The arts coordinator replied that five fibreglass moulds of shields had already been made, waiting to be painted by Roy Gibson. The arts coordinator wrote that 'although he is not copying any exact patterns his designs will be 
informed by traditional designs from the area'. Roy Gibson presented four of the fibreglass shields at the Cairns Indigenous Arts Fair (CIAF) in 2009, but none with the design from the shield in the Roth collection at the Australian Museum (Figure 11).

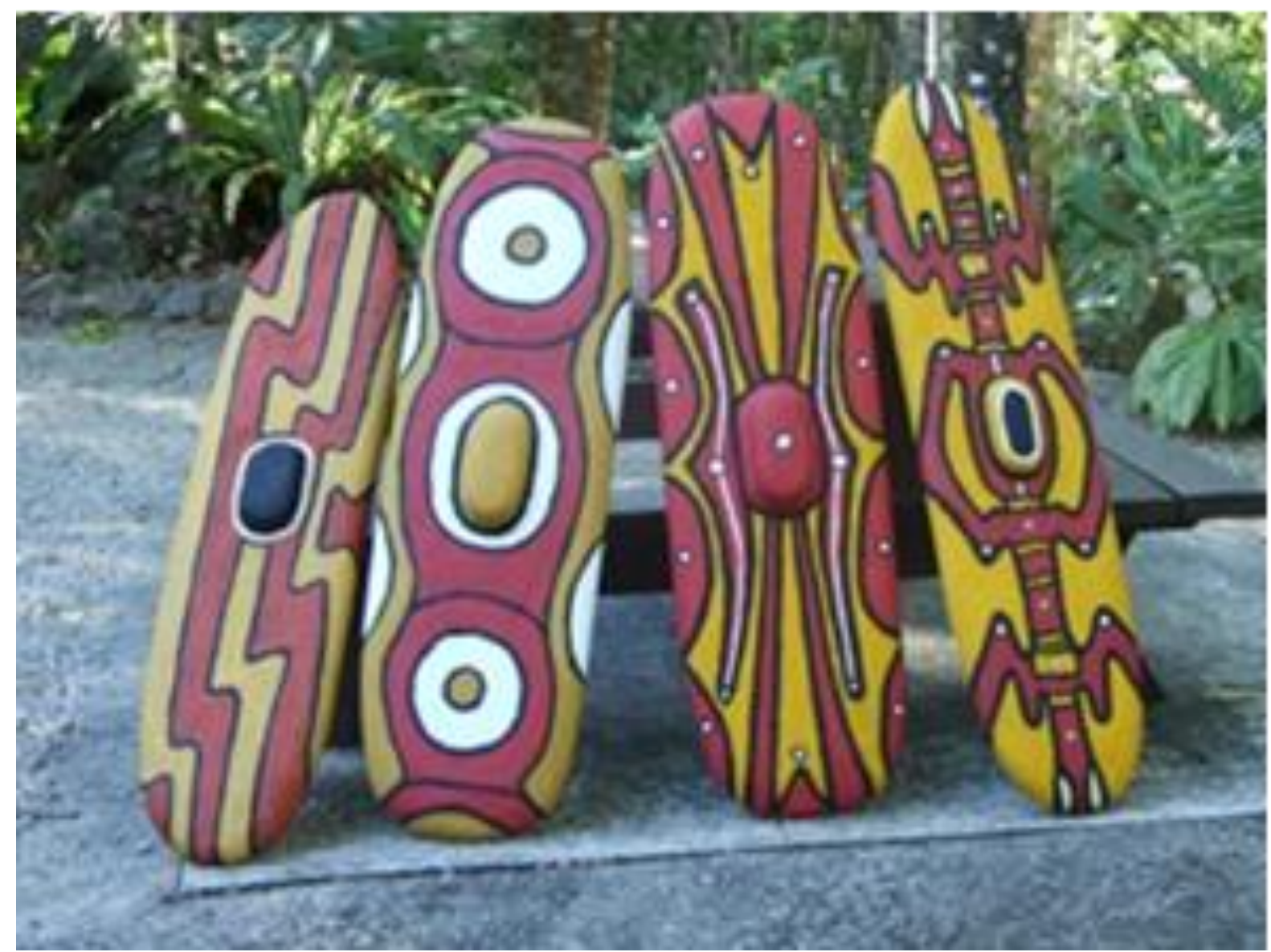

Figure 11: Shields by Roy Gibson (C) 2009, Yalanji Arts, Mossman Gorge Community. Photograph by Theresa Brown.

Two years later, at the Cairns Indigenous Arts Fair of 2011, the design on the shield held in the Roth collection in the Australian museum and some of Roy's own shield designs reemerged in a design on a silk scarf (Figure 12). This design has since been printed onto porcelain cups, saucers and bowls as well as on iPad-covers, oven gloves and aprons, for sale to tourists the Mossman Gorge Cultural Centre.

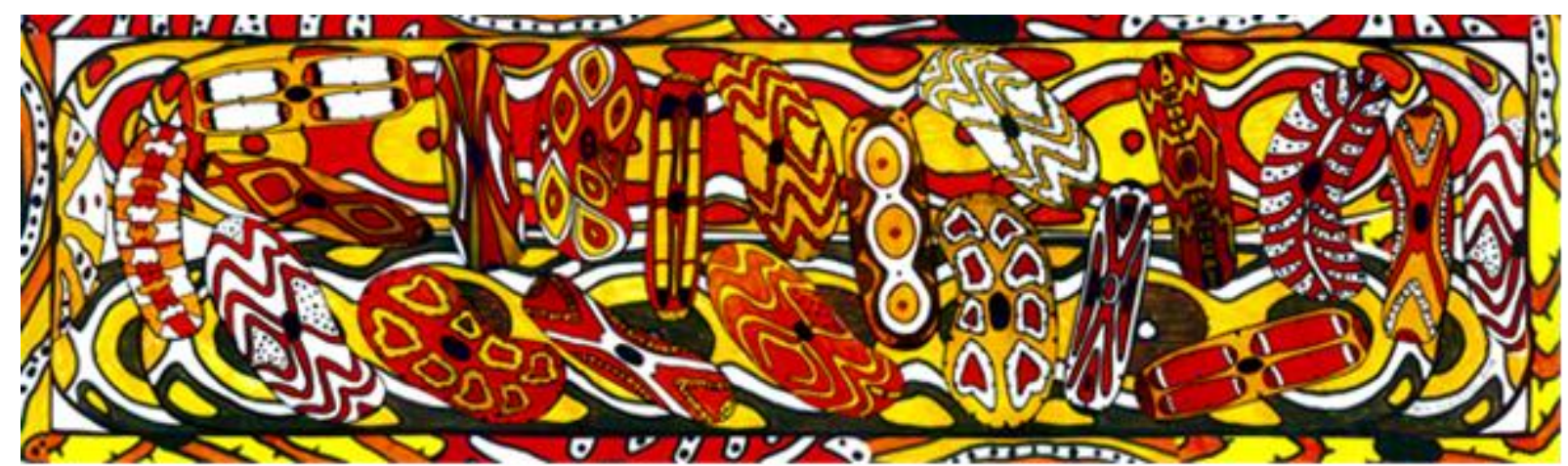

Figure 12: Design by Roy Gibson @ ( 2010, Yalanji Arts, Mossman Gorge Community 
Thus, the scarf brings together both traditional and contemporary Kuku Yalanji designs and archived knowledge with living knowledge.

\section{The Past in the Present: The Significance of Blood}

Our ethnographic research with Aboriginal people today indicates that particular cosmological significance is given to the use of human blood in the painting of rainforest shields and baskets. However, McConnel does not mention the use of blood. She notes that either water or grease was mixed with charcoal for painting the shields she collected in 1930 (50). It may be that blood was used in some shields but not others. Perhaps the Aboriginal artists did not wish to imbue the shields that they were making for sale to McConnel with their blood. It may be that Aboriginal painters avoided putting their own blood on shields and baskets that were specifically made for sale to European collectors, but it may also be the case that this was a common practice traditionally in trade and exchange in the Aboriginal domain as well. In other words, blood may have been used only on shields and baskets that a man painted in connection with ritual processes, such as initiation and mortuary rites. For some Aboriginal people the idea of blood enhances connections between past and present. This was illustrated in an interview with a rainforest man who told us that some people considered undertaking DNA analysis on blood on old shields in order to 'prove' connection with contemporary individuals. He said that the collectors of the shields held in museums tended to record the places where they procured the shields and sometimes even the name of the tribe, but they did not record the names of the particular men who painted the shields with their own blood. He said it was not enough for him to know that a shield was a Yidinji shield. He was seeking corporeal connections of substance between the original makers, the 'old people' and their descendants alive today.

How rainforest artists today engage with the shields is indeed informed by ideas and concepts remembered and transmitted by the 'old people' (Langton; Henry 211-12). But these fragments of the past are reworked into thoroughly contemporary cosmologies and ontologies that inform not only the art works themselves but also practices of production and exchange.

We discussed the use of blood in painting with a number of artists who were exhibiting their work at the Cairns Indigenous Arts Fair in 2012. According to Leonard Andy, a Djiru Traditional Owner of the Mission Beach area, artists today will sometimes use cow or pigs blood from the butcher to mix with charcoal or ochre as a fixative. When asked whether he would consider using his own blood to paint the shield he was making, he said if he did that he would not feel right about selling it. He would keep such a shield or perhaps give it as a gift to someone. Asked the same question, Paul Bong said he did not use blood as he painted with acrylics, not ochre. He said even if he painted with ochre he would not wish to mix it with his own blood. Bong stressed that the designs that he painted on his shields were informed by traditional designs. He said that his totemic design was that of the scorpion and in his artwork he was innovating with elements of designs that could be found on traditional shields that are today in museum collections.

Greer following Sansom reports on 'irruptions' that occur in relation to archaeological sites in northern Cape York. She refers to these as 'portals' through which one is transported to another place or state:

Artefacts and sites are embedded within networks of practices; their authenticity deriving from their creation by people who can be directly linked with both the 
'archaeological past' and with bifor taim. It is as if the objects themselves link humans across time and space. (Greer 55)

On a recent fieldtrip (20-21/4/2012) Bård Aaberge asked Kuku Yalanji artist, Roy Gibson, about the inspiration or creative source that he attributed to the designs he put on his four shields exhibited at CIAF. According to Gibson, the designs 'came to him', not in a nocturnal dream, but while he was awake. He also said that he did not make these designs up, they were 'already there'. Kuku Yalanji people see some dreams or visions as ancestral in origin, which are then incorporated into the corpus of traditional knowledge (Aaberge; see also Myers and Glaskin). In Western tradition, this may be seen as human innovation, but for Kuku Yalanji people this is not 'new' knowledge, but a recovery of lost or forgotten knowledge. The idiom is 'remembering' one's Dreaming, which implies that the Dreaming always exists in potentia, if not in manifested knowledge. Such revelation, typically through dreams, displays a different temporality in which the past is continually part of a dynamic present, where "present activities become "charged" with the ancestral past, and the ancestral past with the present' (Munn 114).

\section{Conclusion}

In this paper we have explored how some iconic rainforest things have been valued through time by considering the creative energies that both collectors and Aboriginal people have put into them. We have argued that creative energy can be observed not only in the making of things but also in the way social relationships are built through transactions in these things, including ritual processes and networks of trade and exchange, both among Aboriginal people and between them and the European collectors. The collectors and museums, in turn, invested creative energy in the procurement of the objects and in curating and displaying them.

Aboriginal artists today engage with museum artefacts as a means of accessing the knowledge and skills of their ancestors. The mutual influence between archival and contemporary Indigenous art presents us with a dynamic field for reflection on form and expression of emerging individual, communal and ancestral agencies.

The museum artefacts are seen as being imbued not only with ancestral spirit but also with actual bodily substance, blood and sweat, of the old people who made them. In engaging with these things artists are not only seeking knowledge and inspiration, but also substantiating and authenticating their connections to the 'old people'. In doing so, they recompose and weave sometimes politically fraught new relationships of identity and difference, from the creative energy of the 'everywhen' (Stanner 58) accessible through the shields and baskets that their 'old people' made.

\section{Acknowledgements}

The research for this paper was funded by an Australian Research Council (ARC) Discovery grant for the project 'Objects of possession: Artifact transactions in the Wet Tropics of North Queensland, 1870-2013' (DP110102291). We have benefitted immensely from discussions with the other investigators involved in this project, including Michael Wood, Russell McGregor, Maureen Fuary and Corinna Erckenbrecht. We presented this paper at the 'Values 
of Dominance and Difference' Colloquium organized by The Cairns Institute, in collaboration with the Universities of Aarhus (Denmark) and Bergen (Norway) and the TransOceanik International Associated Laboratory (CNRS, EHESS, Collège de France and JCU), 9-11 August 2012. We are immensely grateful to Steffen Dalsgaard (Aarhus), Bruce Kapferer (Bergen) and Ton Otto (JCU) for convening this colloquium and to the other invited participants for their valuable feedback during the discussion. A part of this paper was also presented at the conference 'Between Creolization and Indigeneity: Ambiguous Memories and Creative Responses in the Tropical worlds (Indian Ocean, Pacific, Atlantic) organised by the LIA TransOceanik, convened by Barbara Glowczewski and hosted by the Laboratory 'Textes, langues, communications dans les espaces créolophones et francophones' (LCF) and the Observatory of Societies of the Indian Ocean (OSOI), at the Universite of la Réunion.

\section{Works Cited}

Aaberge, Bård Rydland. 'Aboriginal Dreamings and Existence: Living with the Kuku Yalanji.’ Diss. Cand. Polit. (MA), University of Bergen, 2007.

Abernethy, Lillian May. 'Rainforest Aboriginal Shields: Analysis of a Technological Style.' Diss. Graduate Diploma in Material Culture, James Cook University, Townsville, 1984.

Alland, Alexander. 'A Design Analysis of Maring Shields.' Displays of Power: Art and War among the Marings of New Guinea. Ed. C. Lowman. New York: The Museum of Primitive Art Studies, Number 6, 1973. 33-44.

Allen, Lindy. 'Regular Hunting Grounds: A History of Collecting Indigenous Artefacts in North Queensland.' Story Place: Indigenous Art of Cape York and the Rainforest. Brisbane: Queensland Art Gallery, 2004. 30-37.

Best, Anne. Regional Variation in the Material Culture of Hunter Gatherers: Social and Ecological Approaches to Ethnographic Objects from Queensland, Australia. Oxford: British Archaeological Reports, International Series 1149, 2003.

Boyer, Alain-Michel. 'The Universality of Shields.' Shields: Africa, Southeast Asia and Oceania. Munich: Prestel Verlag, 2000. 8-31.

Carrier, James. 'Property and Social Relations in Melanesian Anthropology.' Property Relations: Renewing the Anthropological Tradition. Ed. C.M. Hann. Cambridge: Cambridge University Press, 1998. 85-103.

Erckenbrecht, Corinna, et al. 'Artefacts, Collectors and the Definition of a "Region" in the Tropics of North Queensland.' The Australian Journal of Anthropology 21 (2010): 350-66.

Erckenbrecht, Corinna. Auf der Suche nach den Ursprüngen - Die Australienreise des Anthropologen und Sammlers Hermann Klaatsch 1904-1907 [The Australian Journey (1904-1907) of the German Anthropologist and Collector Hermann Klaatsch]. Ethnologica N.F. 27. Köln: Wienand-Verlag, 2010.

Evans-Pritchard, E.E. The Nuer. Oxford: Clarendon Press, 1940. 
Ewington, Julie. 'Working in the River: Baskets of the Rainforest.' Story Place: Indigenous Art of Cape York and the Rainforest. Brisbane: Queensland Art Gallery, 2003. 158163.

Ferrier, Asa. 'Dr Eric Mjoberg's 1913 Scientific Exploration of North Queensland's Rainforest Region.’ Memoirs of the Queensland Museum Cultural Heritage Series 4.1 (2004): 1-27.

Foster, Robert J. 'Art/Artefact/Commodity: Installation Design and the Exhibition of Oceanic Things at two New York Museums in the 1940s.' The Australian Journal of Anthropology 23.2 (2012): 129-157.

Gell, Alfred. Art and Agency: An Anthropological Theory. Oxford: Clarendon Press, 1998.

Glaskin, Katie. 'On Dreams, Innovation and the Emerging Genre of the Individual Artist.' Anthropological Forum, 20 (2010): 251-267.

Graeber, David. 'Value: Anthropological Theories of Value.' A Handbook of Economic Anthropology. Ed. J. Carrier. Cheltenham, UK: Edward Elgar, 2005. 439-454.

Greer, Shelley. 'Portals in a Watery Realm: Cultural Landscapes in Northern Cape York.' Historic Environment 22.1 (2009): 38-43.

Greer, Shelley. 'Heritage and Empowerment: Community-based Indigenous Cultural Heritage in Northern Australia.' International Journal of Heritage Studies 16.1 (2010): 45-58.

Gregory, C.A. Savage Money: The Anthropology and Politics of Commodity Exchange. Amsterdam: Harwood, 1997.

Hale, Ranna. 'Painted Designs on Rainforest Aboriginal Shields from North Queensland: An Analysis of Correlation between Design Styles and Geographical Distribution.' Diss. Graduate Diploma of Material Anthropology, James Cook University, Townsville, 1989.

Henare, Amiria J.M. Museums, Anthropology and Imperial Exchange. Cambridge: Cambridge University Press, 2005.

Henry, Rosita. Performing Place, Practising Memories: Aboriginal Australians, Hippies and the State. New York and Oxford: Berghahn Books, 2012.

Henry, Rosita, Ton Otto, and Michael Wood. 'Ethnographic Artefacts and Value Transformations.' HAU: Journal of Ethnographic Theory 3.2 (2013): 33-51.

Johnson, Trish. 'Shared Stories and Places: Art of the Rainforest.' Story Place: Indigenous Art of Cape York and the Rainforest. Brisbane: Queensland Art Gallery, 2003. 150157.

Kirshenblatt-Gimblett, Barbara. Destination Culture: Tourism, Museums, and Heritage. Berkeley: University of California Press, 1998. 
Langton, Marcia. 'The Edge of the Sacred, the Edge of Death: Sensual Inscriptions.' Inscribed Landscapes: Marking and Making Place. Eds B. David and M. Wilson. Honolulu: University of Hawai'i Press, 2002. 253-269.

Lowman, Cherry. Displays of Power: Art and War among the Marings of New Guinea. New York: The Museum of Primitive Art Studies, Number 6, 1973.

Lumholtz, Carl. Among Cannibals: An Account of Four Years Travels in Australia and of Camp life with the Aborigines of Queensland. London: John Murray, 1889.

McConnel, Ursula. 'Inspiration and Design in Aboriginal Art.' Art in Australia 59 (1935): 49-68.

Mountford, Charles P. Australian Aboriginal Art : Decorated Shields of North Queensland, Melbourne, Newcraft Publicity, 1968.

Munn, Nancy. 'The Cultural Anthropology of Time: A Critical Essay.' Annual Review of Anthropology 21 (1992): 93-123.

Myers, F. R. Pintupi Country, Pintupi Self: Sentiment, Place, and Politics among Western Desert Aborigines. Canberra: Australian Institute of Aboriginal Studies, 1986.

O'Hanlon, Michael and Welsch, Robert L. eds. Hunting the Gatherers: Ethnographic Collectors, Agents and Agency in Melanesia, 1870s-1930s. New York; Oxford: Berghahn Books, 2000.

Ortner, Sherry. Anthropology and Social Theory: Culture, Power, and the Acting Subject. Durham, N.C.: Duke University Press, 2006.

Pearson, Les. Derwent Vallace (1875-1960): A Family Story, Cairns, n.d.

Penny, Glenn H. Objects of Culture: Ethnology and Ethnographic Museums in Imperial Germany. Chapel Hill: University of North Carolina Press, 2002.

Peterson, Nicolas, Lindy Allen, and Louise Hamby. eds. The Makers and Making of Indigenous Australian Museum Collections. Carlton: Melbourne University Press, 2008.

Sansom, Basil. 'Irruptions of the Dreaming in Post-colonial Australia.' Oceania 72.1 (2001): $1-32$.

Stanner, William E. H. The Dreaming \& Other Essays. Melbourne: Black Inc. Agenda, 2009.

Strathern, Marilyn. 'Divisions of Interest and Languages of Ownership.' Property Relations: Renewing the Anthropological Tradition. Ed. C.M. Hann. Cambridge: Cambridge University Press, 1998. 215-231 